\title{
Determinants of the Shadow Economy in the Czech Regions: A Region-Level Study
}

\section{Jakub Buček ${ }^{1}$}

\begin{abstract}
This paper investigates the size and development of the shadow economy in the Czech Republic on the state-level base over the 2005-2014 period. The multiple indicators multiple causes (MIMIC) model is used to assess the estimation of the shadow economy size. I investigate how labour market, number of people with at least one distraint, and the burden of taxation might contribute to the existence of the shadow economy. While the former two are important determinants of the shadow economy, I find no evidence to prove any significant impact of distraints on the shadow economy size. As for the country's particular regions, I find that those surrounding big cities, especially Prague, have, on average, a smaller shadow economy size, whereas regions in the borderlands (former Sudetenland) suffer from a larger shadow economy.
\end{abstract}

Key words: Shadow Economy, MIMIC Model, Regions, Tax Burden

JEL Classification: $\mathrm{O} 17, \mathrm{H} 26$

Received: 12 June 2017 / Accepted: 8 August 2017 / Sent for Publication: 12 September 2017

\section{Introduction}

The shadow economy is a worldwide phenomenon that is gaining more and more attention from both economists and politicians. The size of shadow economies in developed countries had been increasing during the 1990s (Schneider, 2000), but it started to slowly decrease in the new millennium (Schneider, 2015). In the case of the Czech Republic, the size of the shadow economy had reduced from the level of $19.5 \%$ of GDP in 2003 to the level of $15.1 \%$ of GDP in 2015 with a minor peak during 2009 recession (Schneider, 2015). The above mentioned is in agreement with findings of Elgin and Öztunali (2012), who have confirmed the increasing trend of the Czech shadow economy size until the mid-1990s as well as the decreasing trend afterwards.

While the size of the shadow economy in the Czech Republic has in the long term been below the EU average (Schneider, 2015), the current government of the Czech Republic has declared the fight against tax evasion as one of the priorities ${ }^{2}$. The law introducing

\footnotetext{
${ }^{1}$ Faculty of Economics and Administration, Masaryk University, Lipová 41a, Brno, Czech Republic, jakubbucek@mail.muni.cz

${ }^{2}$ See, Policy statement of the government of the Czech Republic, February 2014.
}

(c) 2017 by the authors; licensee Review of Economic Perspectives / Národohospodárský obzor, Masaryk University, Faculty of Economics and Administration, Brno, Czech Republic. This article is an open access article distributed under the terms and conditions of the Creative Commons Attribution 3.0 license, Attribution - Non Commercial - No Derivatives. 
the obligation of electronic registration of sales passed in March $2016^{3}$, bringing the problem of the shadow economy to light.

The definition of shadow economy is not clear and varies across literature. As defined by Schneider and Williams (2013, p. 25), the broadest definition of shadow economy could be "unreported income from the production of legal goods and services, either from monetary or barter transactions - and so includes all productive economic activities that would generally be taxable were they reported to the state (tax) authorities." For the purpose of the paper, I use this definition, despite the fact that the chosen method can capture clearly illegal activities (e.g. drug production and distribution) that are not stated in the above-mentioned definition as well. On the other hand, the European System of Accounts ${ }^{4}$ (ESA 2010) takes this kind of illegal activities into account when computing the national product. Since Czech public organisations adapt the ESA standards, these activities are included in the data used in this paper. The chosen method can partly filter out the influence of this illegal behaviour on the estimation of the size of the shadow economy; and thus the definition by Schneider and Williams is sufficient for the purpose of the paper.

The research of a shadow economy is very important for policymakers as underground activities often undermine their intentions and, therefore, can have important implications for the economic policy. Simply put, large shadow economies imply smaller tax bases, which may result in higher budget deficit or tax rates (Schneider and Enste, 2000). Because of high tax rates, individuals can feel overburdened by the state and might respond with engaging in even more underground activities. On the other hand, a shadow economy can provide opportunities for people struggling to find a job (e.g. as the result reason of rising minimal wage), and it also makes some services which are not profitable under current legislation available (e.g. a grocery shop in small villages).

The purpose of this paper is to construct estimations of the size of the shadow economy in the Czech Republic on the state-level base over the 2005-2014 period. Although the Czech shadow economy on the national level has been a subject of many cross-country studies, this paper presents, to my knowledge, the first attempt to measure Czech regions' individual shadow economies. The multiple indicator multiple cause (MIMIC) model is used to get annual time series of estimates for each region. As its name suggests, the MIMIC model takes into account several indicators and causes of a shadow economy to assess an unobserved shadow economy. In this paper, I determine how direct and indirect taxes, labour market and number of people with at least one distraint affect the shadow economy size.

(https://www.vlada.cz/assets/media-centrum/dulezite-dokumenty/en_programove-prohlasenikomplet.pdf)

${ }^{3}$ See, Act on Registration of Sales No. 112/2016 Col., March 2016. (http://www.etrzby.cz/assets/cs/prilohy/Act-on-Registration-of-Sales-No-112-2016-Coll.pdf)

${ }^{4}$ See, Regulation (EU) No 549/2013 of the European parliament and of the Council on the European system of national and regional accounts in the European, May 2013. (http://eurlex.europa.eu/legal-content/EN/TXT/PDF/?uri=CELEX:32013R0549\&from=EN) 
The remaining of the paper is organized as follows: Section 2 presents methods of measurement of the shadow economy that are used in the literature, with a focus on the MIMIC model. Section 3 provides a discussion of the possible causes and indicators of the shadow economy. Section 4 provides an overview of data used in an empirical analysis. Section 5 provides the empirical results; and Section 6 concludes the investigation.

\section{Measurement of the Shadow Economy}

Estimating the size and trend of the shadow economy is a complicated and challenging task. Schneider and Williams (2013) divide techniques of estimation of the shadow economy size into 3 categories: direct procedures, indirect procedures, and structural models. Direct procedures, primarily including surveys and tax audits, provide the lowest estimates of the shadow economy out of the three methods. Because of the illegal nature of the shadow economy, people do not want to uncover their share in it and the survey must be sophisticated enough so as not to reveal its real purpose at first glance. Also, people (partly) working in the shadow economy are often unaware of their involvement in it. In other words, they do not know that they are doing something illegal. Indirect methods make use of macroeconomic indicators as a proxy to development of the shadow economy (e.g. comparison of GDP measured by income versus expenditure approach, or development of total electricity consumption). The third category employs statistical models that treat the shadow economy as a latent (unobserved) variable. These methods include the structural equation model (SEM) and the dynamic stochastic general equilibrium (DSGE) model. The former examines statistical links between observed and unobserved variables (see, for example, Frey and Weck-Hanneman (1984), Buehn (2011), Wiseman (2013)), whereas the latter is based on the rational behavior of agents (see, for example, Orsi et al. (2014), Argentiero and Bollino (2015), Pappa et al. (2015), or Annicchiarico and Cesaroni (2016)).

According to Schneider and Williams (2013), the most commonly used method to estimate the size of the shadow economy is based on the combination of the multiple indicator multiple cause (MIMIC) model, which is part of the SEM family, and the currency demand method, which is part of indirect procedures; or, alternatively, only the currency demand method is used. The advantage of the MIMIC approach is that several indicators of the latent variable can be taken into account simultaneously. Unfortunately, the disadvantage of the MIMIC procedure is that it only provides relative estimates of the latent variable. Thus, a different method needs to be employed to calibrate the relative value into absolute value estimates.

Despite the increasing number of publications on the shadow economy, only a few studies have examined the shadow economy on the regional level of a particular nation (e.g. Chaudhuri et al. (2006), Tafenau et al. (2010), Buehn (2011), or Wiseman (2013)). In these studies, the standard approach to estimate size of the shadow economy is the MIMIC model. For these reasons, the MIMIC model is used to assess the size of the shadow economy in this paper as well.

The MIMIC model can be demonstrated on the following system of linear equations:

$$
I=\alpha \cdot S+\epsilon
$$




$$
S=\beta^{\prime} \cdot C+v
$$

where $\alpha, \beta$ are vectors of coefficients, vector $I$ contains all indicators of the shadow economy, vector $C$ contains all causes of the shadow economy, and $S$ is the latent variable representing the shadow economy. Error terms $\epsilon$ and $v$ are assumed to be uncorrelated.

Substituting equation (2) into equation (1) yields the following equation:

$$
I=\gamma \cdot C+\delta
$$

where $\gamma=\alpha \cdot \beta^{\prime}$, and $\delta=\alpha \cdot v+\epsilon$. To estimate the equation (3), normalization of the model (1) is required. This is accomplished by setting one element of vector $\alpha$ equal to 1. The model is estimated via the maximum likelihood estimation and then the relative size of the shadow economy is computed from equation (2).

\section{Determinants and Indicators of the Shadow Economy}

The first attempt to create a theoretical model of income tax evasion was published by Allingham and Sandmo (1972). They assume that individuals can hide a proportion of their true income from the tax authority to avoid paying a flat income tax from the unreported income. The willingness to commit tax evasion depends on three factors: the tax rate, the probability of detection, and the penalty. The higher the tax rate, the higher the benefit of tax evasion. Nonetheless, an increase in the probability of detection as well as in the penalty increases the expected cost of tax evasion and decreases one's motivation to cheat. Besides these three factors I consider the following determinants and indicators of the shadow economy.

\section{Determinants of the Shadow Economy}

A prominent place in the shadow economy literature is occupied by the analysis of the tax burden. Schneider and Williams (2013) have identified the tax burden as the leading contributor to the shadow economy size. The tax system in the Czech Republic is composed of both direct and indirect taxes. Until 2008, the tax on personal income was progressive with tax rate ranges from $12 \%$ to $32 \%$. Since 2008 , the tax on personal income is flat tax with tax rate $15 \%$. The corporate tax rate has decreased within the observed time period from $24 \%$ to $19 \%$. Finally, goods in the Czech Republic are subject to the value-added tax. There are two VAT rates: the basic one that has gradually increased from $19 \%$ to $21 \%$ since 2007 , and the reduced one that has increased from $5 \%$ to $15 \%$ within the same period. I expect a positive correlation for both direct and indirect taxes to the shadow economy.

The shadow economy largely depends on the labour market regulations. These regulations can be of several forms - minimal wage, compensation requirements, union activity, etc. (Kucera and Roncolato, 2008). In the case of the Czech Republic, such regulations are unified for the whole country and, therefore, are not taken into consideration in my analysis. Instead, I use the unemployment rate, the self-employment rate, and the number of foreigners. According to Wiseman (2013), when formal employment is harder to find, the relative benefits of working in the shadow economy are greater. Thus, the positive correlation between the unemployment rate and the size of the shadow econo- 
my is expected. The choice of using the self-employment rate as a determinant is inspired by a study by Kleven et al. (2011) that deals with a higher level of tax evasion for people with a large share of self-reported income. These individuals typically are selfemployed, whereas tax evasion of people with third-party information reporting is virtually nil. Finally, Leonard (1998) has documented that most workers in the shadow economy are immigrants; that is why the number of non-EU foreigners is considered as one of the determinants.

Because of the uneven distribution of population across the country, the population density is considered as one of determinants as well (Buehn, 2011). I expect a negative relationship between the population density and the shadow economy. The regions with a low population density, typically rural or border regions, do not offer as many employment opportunities as the regions with a higher population density do, typically big agglomerations of national importance.

The last determinant taken into account in each region is the number of people with at least one distraint. To illustrate on a simple example: the debtor wants to hide part of their income from the creditor, and shifts some of their activities to the shadow economy. The higher the number of people with distraints, the larger the shadow economy. Unfortunately, the data available only contains the total number of distraints, which may cause some bias in the results. Nevertheless, I assume that the distribution of people with multiple distraints is homogenous across the whole country, and so the total number of distraints should be a sufficient proxy of the number of people with at least one distraint.

\section{Indicators of the Shadow Economy}

As mentioned above, one can take into account more indicators simultaneously. Buehn (2011) suggests that two dimensions of regional shadow economy activities should be considered: the regional level of prosperity and the potential for future prosperity. As an indicator of the regional level prosperity he uses the economic growth. A higher growth indicates a growing wealth of the region and offers a job opportunity for the local population. An alternative measure for the level of prosperity might be the per-capita income. In both cases, the relationship between the level of prosperity and the shadow economy should be negative as the increasing shadow economy can reduce tax revenue, which leads to a lower quantity and quality of publicly provided goods and, therefore, a lower growth rate of the official economy.

As a proxy for a future prosperity potential, Buehn (2011) employs the measurement of a new entrepreneurial activity in the regions. A new entrepreneurial activity signals the region's potential future prosperity and is likely to generate new employment opportunities in the medium term. Thus, a negative correlation with the size of the shadow economy is expected. It is relevant to also mention here that firms that hide in an underground economy usually have a limited access to the capital market and opportunities for growth (e.g. cannot publicly advertise their products) and are therefore motivated to open a legal business.

Another widely used indicator of the shadow economy is currency in circulation. Unfortunately, such data are not available for the Czech Republic on the regional level. Instead, the total electricity consumption is used. This indicator has been widely used to 
estimate the shadow economy since the 1990s, mainly for estimation of the shadow economy of transitional countries of Central and Eastern Europe (Lacko, 1999). The motivation behind using the total electricity consumption as the indicator of the shadow economy is the assumption that it captures the consumption of electric power in both the formal and shadow economy. One of the criticisms of using the electricity consumption is that it does not capture other sources of energy used in the shadow economy (e.g. natural gas, petrol). I anticipate a positive correlation between the electricity consumption and size of the shadow economy.

Finally, Wiseman (2013) suggests employing labour force participation as one of the indicators. Because the shadow economy extracts labour from the official sector, it only seems reasonable to take the labour force participation into account as one of the indicators of the shadow economy as well. As the labour force participation declines relative to the broader population, those who are not formally employed or job-seeking are more likely to look for work in the shadow economy. Thus, the labour force participation is in a negative relationship to the shadow economy.

The structure of the MIMIC model, mainly the relationship between the determinants and indicators of the shadow economy, and the shadow economy itself, is displayed in Figure 1.

Figure 1 MIMIC model path diagram

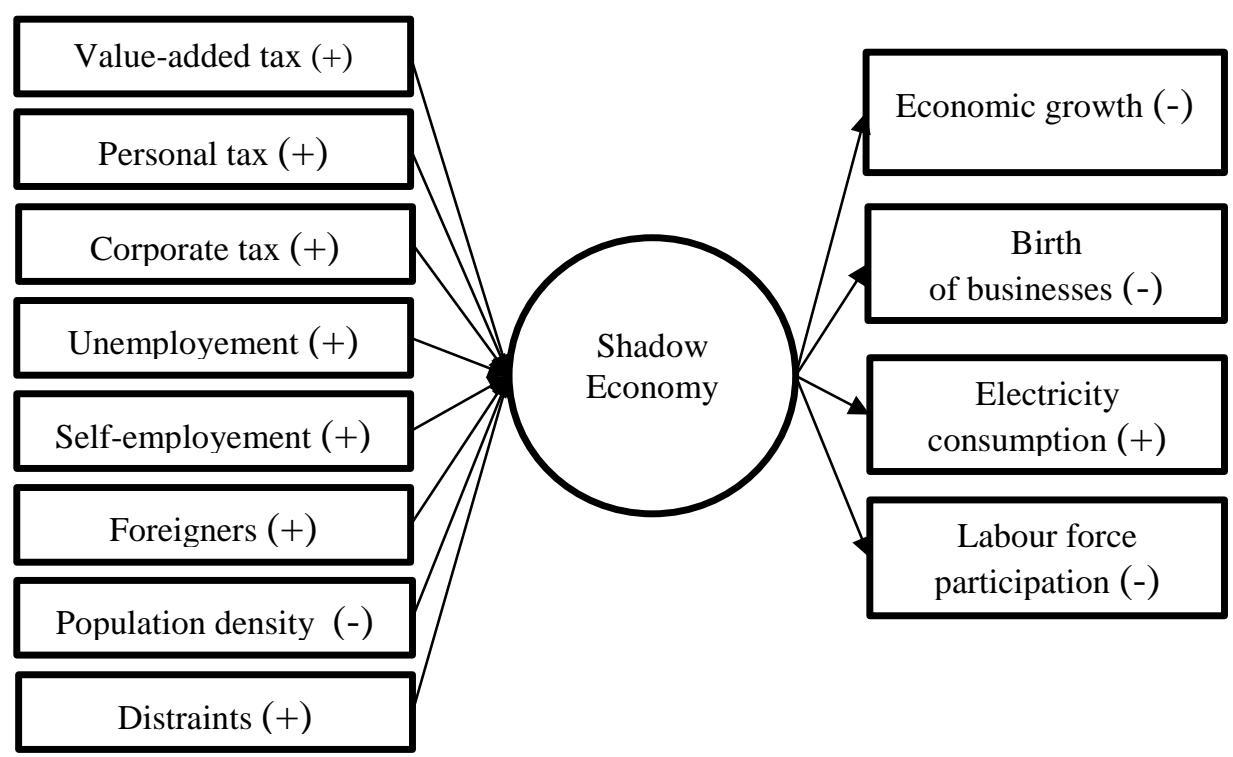

Source: Author.

\section{Data}

Data are collected over the 2005-2014 period. Although the intention was to get the time span as long as possible, some of the pre-2005 or post-2014 data were not available. 
Statistics about number of distraints per region are only available after the year 2010 and about birth of businesses after the year 2007, hence these two determinants are only used in separate analyses. Unfortunately, neither statistics about a probability of tax evasion detection nor any other proxy variable are available to public; this determinant is thus not taken into consideration.

Table 1 provides a summary description of the determinants and indicators of the shadow economy in the Czech Republic, which were discussed above. Detailed information about the data sources can be found in Appendix.

Table 1 Description of variables

\begin{tabular}{|c|c|c|c|c|c|c|}
\hline Variable & $\mathbf{N}$ & Mean & SD & Min & Max & Description \\
\hline \multicolumn{7}{|l|}{ Determinants } \\
\hline Value-added tax & 140 & 0.045 & 0.032 & 0.009 & 0.159 & $\begin{array}{l}\text { Proportion of the value added tax } \\
\text { revenue to GDP }\end{array}$ \\
\hline Personal tax & 140 & 0.032 & 0.007 & 0.021 & 0.061 & $\begin{array}{l}\text { Proportion of the personal tax } \\
\text { revenue to GDP. }\end{array}$ \\
\hline Corporate tax & 140 & 0.026 & 0.014 & 0.011 & 0.086 & $\begin{array}{l}\text { Proportion of the corporate tax } \\
\text { revenue to GDP. }\end{array}$ \\
\hline Unemployment & 140 & 0.067 & 0.025 & 0.019 & 0.145 & General unemployment rate. \\
\hline Self-employment & 140 & 0.090 & 0.015 & 0.042 & 0.149 & $\begin{array}{l}\text { Proportion of self-employment to } \\
\text { region population. }\end{array}$ \\
\hline Foreigners & 140 & 0.023 & 0.020 & 0.005 & 0.095 & $\begin{array}{l}\text { Proportion of the number of non-EU } \\
\text { foreigners to region population }\end{array}$ \\
\hline $\begin{array}{l}\text { Population } \\
\text { density }\end{array}$ & 140 & 291.6 & 611.2 & 62.4 & 2538.0 & $\begin{array}{l}\text { Number of population per square } \\
\text { kilometre. }\end{array}$ \\
\hline Distraints & 70 & 0.078 & 0.025 & 0.043 & 0.149 & The number of distraints per capita. \\
\hline \multicolumn{7}{|l|}{ Indicators } \\
\hline $\begin{array}{l}\text { Economic } \\
\text { growth }\end{array}$ & 140 & 0.010 & 0.038 & -0.078 & 0.094 & Economic growth. \\
\hline $\begin{array}{l}\text { Birth of } \\
\text { businesses }\end{array}$ & 112 & 0.010 & 0.003 & 0.006 & 0.024 & $\begin{array}{l}\text { Proportion of the number of new } \\
\text { businesses to the total number of } \\
\text { businesses in region. }\end{array}$ \\
\hline $\begin{array}{l}\text { Electricity } \\
\text { consumption }\end{array}$ & 140 & 0.019 & 0.007 & 0.005 & 0.039 & $\begin{array}{l}\text { Electricity (kilowatt hours) con- } \\
\text { sumed as a proportion of GDP. }\end{array}$ \\
\hline $\begin{array}{l}\text { Labour force } \\
\text { participation }\end{array}$ & 140 & 0.000 & 0.007 & -0.030 & 0.015 & Growth in labour force participation. \\
\hline
\end{tabular}

Source: See Appendix.

\section{Results}

Table 2 provides the results for several MIMIC model specifications. The panel data for all fourteen of the Czech regions are examined over the 2005-2014 period, except the data for models containing number of distraints or the data for birth of businesses. As mentioned above, one element of the vector of the indicators' coefficients must be set to 1. For all specifications the coefficient for electricity consumption is set to 1. Furthermore, all variables are standardized. 
In Specification 1, the value-added tax and personal tax are both statistically significant; however, they do not carry the expected signs. All three of the labour market variables (unemployment, self-employment, and foreigners) are statistically significant. As expected, unemployment and proportion of non-EU foreigners in population are both positively correlated with the shadow economy. Moreover, the results suggest that selfemployment decreases the shadow economy. This is at variance with the findings by Kleven et al. (2011). Importantly, out of the two indicators (excluding the electricity consumption that is fixed to 1) it is only the economic growth that is statistically significant with the negative sign.

Table 2 Results of the MIMIC model

Specification

Determinants

Value-added tax

Personal tax

Corporate tax

Unemployment

Self-employment

Foreigners

Population density

Distraints

Indicators

Electricity consumption

Economic growth

Birth of businesses

Labour force participation

Statistics

CFI

RMSEA
(1)

$-0.240^{* * *}$
$(-2.699)$
$-0.402^{\star \star *}$
$(-4.311)$
-0.064
$(-0.638)$
$0.311^{\star \star *}$
$(4.699)$
$-0.465^{\star * \star}$
$(-5.479)$
$0.702^{\star * *}$

(8.276)

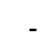

(2)

-0.056
$(-0.573)$
$-0.236^{\star \star}$
$(-2.508)$
0.054
$(0.545)$
$0.304^{* \star \star}$
$(4.822)$
$-0.395^{\star \star}$
$(-4.780)$
$0.847^{\star * \star}$
$(9.511)$
$-0.633^{\star *}$
$(-4.320)$

$(-4.320)$

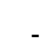

1

$-0.243^{* *}$

$(-2.448)$

$(-3.187)$

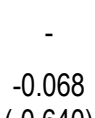

$(-0.640)$

$$
0.891
$$

0.102

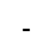

$-0.071$

$(-0.757)$

$$
140
$$

(3)

$-0.091^{\text {** }}$

$0.188^{*}$

$(-2.506)$

$-0.111^{* *}$

$(-2.536)$

0.029

$(0.797)$

$0.059^{\text {** }}$

(2.140)

$-0.105^{\star \star *}$

$(-2.917)$

$-0.212^{* * *}$

(-4.146)

(1.840)

$-0.787^{\star * *}$

$(-6.698)$

$-0.167$

$(-1.587)$

0.105

(1.036)

$-0.913^{* * *}$

$(-5.396)$

$1.110^{\star \star *}$

(6.427)

0.003

$(0.033)$

$$
1
$$

$-0.207$

$(-1.602)$

$-1.986^{* * *}$

$(-5.378)$
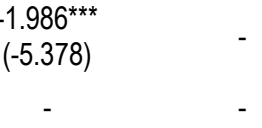

$\begin{array}{lllll}\mathrm{N} & 140 & 140 & 112 & 70\end{array}$

Notes: $R$ software Version 3.3. with lavaan package (Rosseel, 2012) is used for estimation. Absolute z-statistics are in parenthesis below parameter estimates. *, **, and *** denotes statistical significance at the level 10, 5, and $1 \%$, respectively. 
Specification 2 is similar to Specification 1, but the results are controlled by the population density. When the population density is included, the value-added tax loses its statistical significance, while other results still hold. The population density is also statistically significant with negative signs (suggesting smaller size of the shadow economy in densely populated regions). These results are consistent with what has been discussed in the third section of the paper.

Specification 3 somewhat serves as a robust check. I include the same determinants as in the first specification, but I use birth of businesses instead of economic growth or labour force participation as an indicator. Most of the results hold, but value-added tax, personal tax, and unemployment are now statistically significant on the $5 \%$ level, and not on the $10 \%$ level as before. The proportion of non-EU foreigners in population even changes its sign, and the result suggests the opposite to what Specification 1 does.

Finally, the effect of distraints is tested in Specification 4. For this purpose, Specification 1 is modified by adding the variable of interest and removing labour force participation from the indicators. The results show that the assumption about the sign of distraints does not hold as this variable is statistically insignificant.

The negative sign of taxes' coefficient is not in accordance with the theory in either of the four specifications. This inconsistency occurs in many articles where the correlation between taxes and the size of the shadow economy is positive, insignificant or even negative (Johnson et al. 1998, Friedman et al. 2000), as it is in our case. In my view, one of the possible explanations is the fact that lowering tax rates reduces providing public services and these are then replaced by their alternatives sourcing from the shadow economy. Stronger tax revenue also provides a stronger legal environment. However, the causality can be reversed as a larger shadow economy reduces the tax base needed to develop strong institutions and creates the demand for tax cuts.

To evaluate the above specifications, I examine the model fit through two indices: the comparative fit index (CFI) and the root mean square error of approximation (RMSEA). According to $\mathrm{Hu}$ and Bentler (1999), values of the CFA any higher than 0.90 are indicative of an acceptable fit, with values higher than 0.95 suggesting an excellent fit; values of the RMSEA below 0.05 indicate a very good fit, with values less than 0.08 representing an acceptable fit. Unfortunately, none of the models meet the suggested criteria; but values of these characteristics in Specification 1 and 2 are not that far from optimal values.

The shadow economy is then estimated in two steps. Firstly, a relative deviation of the regional shadow economy from country level is constructed by applying the time series to a model specified in Table 2. The Specification 1, which has the best fitting statistics, is used to estimate the relative region-level shadow economy size ${ }^{5}$ :

\footnotetext{
${ }^{5}$ As a robust check, the size of the shadow economy is also estimated using the Specification 2. The results are highly correlated with a 0.9 correlation between these two specifications.
} 


$$
\begin{aligned}
\text { RelShadow }_{i, t}= & -0.240 \cdot \text { VAT }_{i, t}-0.402 \cdot \text { PersonalTax }_{i, t}-0.064 \\
& \cdot \text { CorporateTax }_{i, t}+0.311 \cdot \text { Unemployment }_{i, t}-0.465 \\
& \cdot \text { SelfEmployment }_{i . t}+0.702 \cdot \text { Foreigners }
\end{aligned}
$$

The second step is calibration, which, in this context, means finding the average size of the Czech shadow economy on which the relative deviation can be applied. The estimation of the shadow economy in absolute value is then calculated by adding the average size of the Czech shadow economy (CzechShadowEconomy $y_{t}$ ) to the region's specific relative deviation of the shadow economy from country level (RelShadow $\left.{ }_{i, t}\right)$.

$$
\text { Shadow }_{i, t}=\text { CzechShadowEconomy }_{t}+\text { RelShadow }_{i, t}
$$

For the purpose of this paper, the estimation of the shadow economy by Schneider (2015) is used. As seen in Table 4, the size of the shadow economy in the Czech Republic had always been between $15 \%$ and $18 \%$ of GDP and had decreased over the 20052015 period.

Table 4 Size and trend of the shadow economy in the Czech Republic

\begin{tabular}{lccccccccccc} 
Year & $\mathbf{2 0 0 5}$ & $\mathbf{2 0 0 6}$ & $\mathbf{2 0 0 7}$ & $\mathbf{2 0 0 8}$ & $\mathbf{2 0 0 9}$ & $\mathbf{2 0 1 0}$ & $\mathbf{2 0 1 1}$ & $\mathbf{2 0 1 2}$ & $\mathbf{2 0 1 3}$ & $\mathbf{2 0 1 4}$ & $\mathbf{2 0 1 5}$ \\
\hline $\begin{array}{l}\text { Shadow } \\
\begin{array}{l}\text { Economy } \\
\text { (\% of GDP) }\end{array}\end{array}$ & 18.5 & 18.1 & 17.0 & 16.6 & 16.9 & 16.7 & 16.4 & 16.0 & 15.5 & 15.3 & 15.1 \\
\hline
\end{tabular}

Source: Schneider (2015).

Final estimates of the size of the shadow economy at the regional level in the Czech Republic can be found in Appendix 1. Also, the regions are ranked by their average shadow economy size over the observed period, with 1 indicating the region with the smallest shadow economy, in Appendix 2.

The map of the Czech Republic with the estimated shadow economy is included in Figure 2 to make a better picture. The results show that the smallest shadow economy is in Prague and in the regions surrounding big cities (South Moravian, Plzeň, Zlín, Hradec Králové, and Pardubice regions). The largest shadow economies can be found in the regions in the borderlands, especially in the former Sudetenland (Karlovy Vary, Ústí nad Labem, Liberec, Moravian-Silesian, and Olomouc regions). 
Figure 2 Size of the shadow economy in Czech regions as \% of GDP (2014)

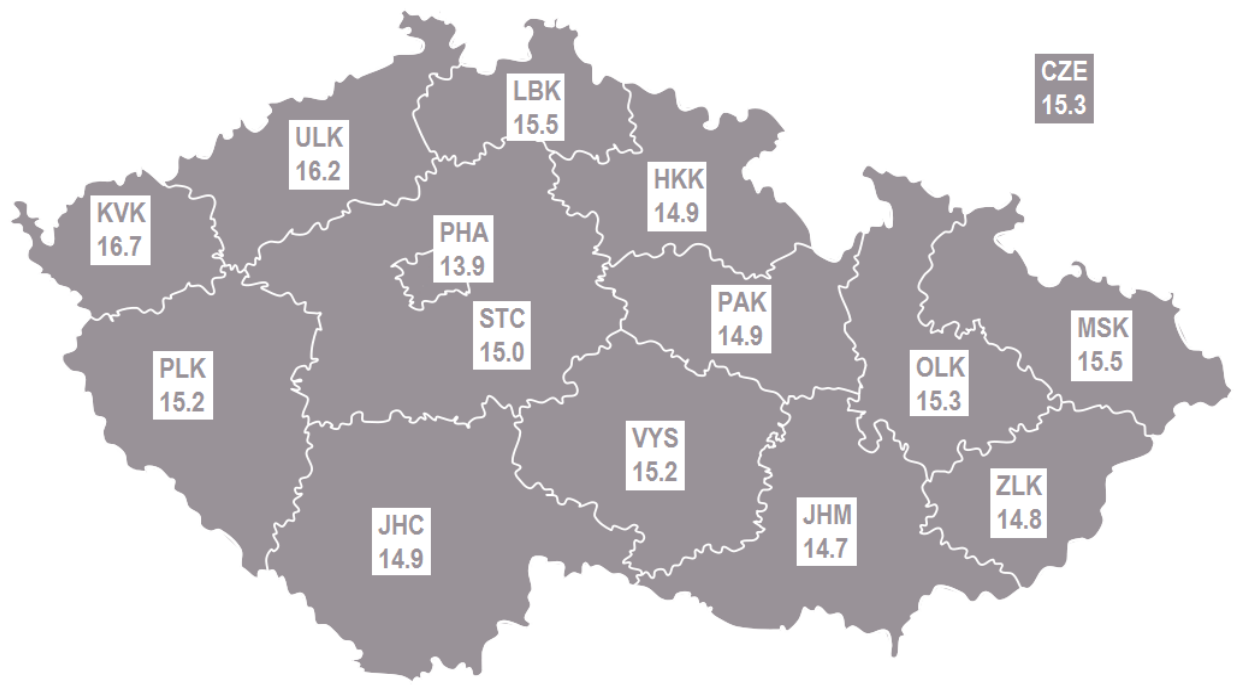

$(C Z E=$ Czech Republic,$P H A=$ Prague, STC $=$ Central Bohemia,$J H C=$ South Bohemia, $P L K=$ Plzeñ, $K V K=$ Karlovy Vary, ULK = Ústi nad Labem, $L B K=$ Liberec, HKK = Hradec Králové, $P A K=$ Pardubice, $V Y S=$ Vysočina,$J H M=$ South Moravia, $O L K=$ Olomouc, ZLK = Zlin, MSK = Moravia-Silesia)

Source: Wikimedia Commons (https://commons.wikimedia.org/wiki/File:CZ-cleneni.svg), Schnei$\operatorname{der}(2015)$, and author.

\section{Conclusion}

This article uses the MIMIC model to estimate the size and trend of the shadow economy at the regional level in the Czech Republic and to identify its causes. Four observed variables are considered as possible indicators of the shadow economy: the economic growth, the new entrepreneurial activity, the consumption of electric power, and the labour force participation. The results indicate that the taxes play an important role to the existence of the shadow economy; however, they do not carry the expected signs. Moreover, the results suggest that corporate taxes do not play an important role to the shadow economy at the regional level.

As for the labour market, results show a positive correlation between unemployment rate, proportion of non-EU foreigners in population and the size of the regional shadow economy. These agree with the findings of other authors. Self-employment is, by contrast, decreasing the shadow economy. I also investigate the effect of the number of people with at least one distraint on the regional shadow economy size. While I anticipated a positive correlation between these two variables, the results indicate no significant correlation at all.

The panel of the estimated shadow economy size for each of the Czech regions over the 2005-2014 period is presented in Appendix. To best of my knowledge, this is the first attempt to estimate the size of the shadow economy for the Czech Republic on the re- 
gional level. Although the chosen approach has its flaws and a certain bias in the estimates of the shadow economy prevails, there are no better data currently available.

Acknowledgements: For helpful comments and suggestions, I would like to thank the participants of the $6^{\text {th }}$ International Scientific Conference TAXES IN THE WORLD in Krakow, and also my university colleagues from the seminar group I.G.O.R.

Funding: This work was supported by the grant No. GA17-26705S of the Czech Science Foundation and the project MUNI/A/1076/2016, a specific research at Faculty of Economics and Administration. This support is gratefully acknowledged.

Disclosure statement: No potential conflict of interests has been reported by the author.

\section{References}

ALLINGHAM, M. G., and A. SANDMO. (1972). Income tax evasion: a theoretical analysis. Journal of Public Economics. Vol. 1, pp. 323-338. DOI: 10.1016/00472727(72)90010-2

ANNICCHIARICO, B., and C. CESARONI. (2016). Tax Reforms and the Underground Economy: A Simulation-Based Analysis. CEIS Research Paper. Vol. 14, pp. 143.

ARGENTIERO, A., and C. A. BOLLINO. (2015). Uncovering Unobserved Economy: A General Equilibrium Characterization. Metroeconomica. Vol. 66, pp. 306-338. DOI: 10.1111/meca.12072

BUEHN, A. (2011). The Shadow Economy in German Regions: An Empirical Assessment. German Economic Review. Vol. 13, pp. 275-290. DOI: 10.1111/j.14680475.2011.00557.x

CHAUDHURI, K., F. SCHNEIDER, and S. CHATTOPADHYAY. (2006). The size and development of the shadow economy: An empirical investigation from states of India. Journal of Development Economics. Vol. 80, pp. 428-443. DOI: 10.1016/j.jdeveco.2005.02.011

ELGIN, C., and O. ÖZTUNALI. (2012). Shadow economy around the world: model based estimates. Working Papers. No. 2012/05, pp. 1-48.

FREY, B. S., and H. WECK-HANNEMAN. (1984). The hidden economy as an 'unobserved' variable. European Economic Review. Vol. 26, pp. 33-53. DOI: 10.1016/00142921(84)90020-5

FRIEDMAN, E., S. JOHNSON, D. KAUFMANN, and P. ZOIDO-LOBATON. (2000) Dodging the grabbing hand: the determinants of unofficial activity in 69 countries. Journal of Public Economics. Vol. 76, pp. 459-493.

HU, L., and P. M. BENTLER. (1999). Cutoff criteria for fit indexes in covariance structure analysis: Conventional criteria versus new alternatives. Structural Equation Modeling: A Multidisciplinary Journal. Vol. 6, pp. 1-55. DOI: 10.1080/10705519909540118 
JOHNSON, S., D. KAUFMANN, and P. ZOIDO-LOBATON. (1998) Regulatory Discretion and the Unofficial Economy. The American Economic Review. Vol. 88, No. 2, pp. 387-392.

KLEVEN, H. J., M. B. KNUDSEN, C. T. KREINER, and S. PEDERSEN. (2011). Unwilling or Unable to Cheat? Evidence From a Tax Audit Experiment in Denmark. Econometrica. Vol. 79, pp. 651-692. DOI: 10.3982/ECTA9113

KUCERA, D., and L. RONCOLATO. (2008). Informal employment: Two contested policy issues. International Labour Review. Vol. 147, pp. 321-348. DOI: 10.1111/j.1564-913X.2008.00039.X

LACKO, M. (1999). Do Power Consumption Data Tell the Story? - Electricity Intensity and Hidden Economy in PostSocialist Countries. Budapest Working Papers on the Labour Market. No. 1999/2, pp. 1-31.

LEONARD, M. (1998). Invisible Work, Invisible Workers: The Informal Economy in Europe and the US. London: MacMillan Press. ISBN 978-0312217600.

ORSI, R., D. RAGGI, and F. TURINO. (2014). Size, trend, and policy implications of the underground economy. Review of Economic Dynamics. Vol. 17, pp. 417-436. DOI: 10.1016/j.red.2013.11.001

PAPPA, E., R. SAJEDI, and E. VELLA. (2015). Fiscal consolidation with tax evasion and corruption. 37th Annual NBER International Seminar on Macroeconomics. Vol. 96, pp. S56-S75. DOI: 10.1016/j.jinteco.2014.12.004

ROSSEEL, Y. (2012). Lavaan: An R Package for Structural Equation Modeling. Journal of Statistical Software. Vol. 48, pp. 1-36. DOI: 10.18637/jss.v048.i02

SCHNEIDER, F. (2000). The Increase of the size of the shadow economy of 18 OECD countries: Some preliminary explanations. CESifo Working Paper Series. No. 306, pp. $1-31$.

SCHNEIDER, F. (2015). Size and Development of the Shadow Economy of 31 European and 5 other OECD Countries from 2003 to 2015: Different Developments.

SCHNEIDER, F., and D. H. ENSTE. (2000). Shadow Economies: Size, Causes, and Consequences. Journal of Economic Literature. Vol. 38, pp. 77-114. DOI: 10.1257/jel.38.1.77

SCHNEIDER, F., and C. C. WILLIAMS. (2013). The Shadow Economy. London: The Institute of Economic Affairs. ISBN 9780255366748.

TAFENAU, E., H. HERWARTZ, and F. SCHNEIDER. (2010). Regional Estimates of the Shadow Economy in Europe. International Economic Journal. Vol. 24, pp. 629-636. DOI: $10.1080 / 10168737.2010 .526010$

WISEMAN, T. (2013). US shadow economies: a state-level study. Constitutional Political Economy. Vol. 24, pp. 310-335. DOI: 10.1007/s10602-013-9146-7 


\section{Appendix 1: Data sources}

\begin{tabular}{|c|c|}
\hline Variable & \\
\hline GDP & $\begin{array}{l}\text { Public database / GDP, National Accounts / Gross Domestic Product in the regions } \\
\text { of the Czech Republic / GDP at current year }\end{array}$ \\
\hline CPI & $\begin{array}{l}\text { Public databasea / Prices, Inflation / Inflation, Consumer Prices / Consumer price } \\
\text { indices according to COICOP - time series / average } 2015=100\end{array}$ \\
\hline $\begin{array}{l}\text { Electricity } \\
\text { consumption }\end{array}$ & Regional database / Statistiky / Průmysl, energetika - Kraj (Czech version only) \\
\hline $\begin{array}{l}\text { Labour force } \\
\text { participation }\end{array}$ & $\begin{array}{l}\text { Public database / Employment, Unemployment / Participation rate of people aged } \\
15 \text { and more - territorial comparison }\end{array}$ \\
\hline Unemployment & $\begin{array}{l}\text { Public database }{ }^{\text {a }} \text { Employment, Unemployment / } \\
\text { General unemployment rate by cohesion regions and regions - annual average }\end{array}$ \\
\hline Self-employment & $\begin{array}{l}\text { O ČSSZd / Informace / Statistiky / Statistické a ekonomické ukazatele / Přehled o } \\
\text { počtu OSVČ dle krajů resp. dle okresů a krajů / vykonávající činnost celkem (Czech } \\
\text { version only) }\end{array}$ \\
\hline Foreigners & $\begin{array}{l}\text { Public database / Foreigners / Foreigners by citizenship as at } 31 \text { December - territo- } \\
\text { rial comparison / Other countries }\end{array}$ \\
\hline Population & $\begin{array}{l}\text { Public databasea / Population / Distribution of the population by age group as at } \\
\text { 31.12.- territorial comparison / Population, total }\end{array}$ \\
\hline Birth of businesses & Public database / Business Register Data / Birth and death of businesses \\
\hline Distraints & $\begin{array}{l}\text { Přehledy agend / S_AS_108 - Přehled o vyřizování agendy EXE - nařizení exekuce } \\
\text { u OS / nápad (Czech version only) }\end{array}$ \\
\hline Value-added tax & $\begin{array}{l}\text { Daně a pojistnéc / Analýzy a statistiky / Daňová statistika / Inkaso za rok / Daň z } \\
\text { přidané hodnoty celkem (Czech version only) }\end{array}$ \\
\hline Personal tax & $\begin{array}{l}\text { Daně a pojistnéc / Analýzy a statistiky / Daňová statistika / Inkaso za rok / Daň z } \\
\text { přijmů právnických osob celkem (Czech version only) }\end{array}$ \\
\hline Corporate tax & $\begin{array}{l}\text { Daně a pojistnéc / Analýzy a statistiky / Daňová statistika / Inkaso za rok / Daně z } \\
\text { přijmů fyzických osob celkem (Czech version only) }\end{array}$ \\
\hline \multicolumn{2}{|c|}{ 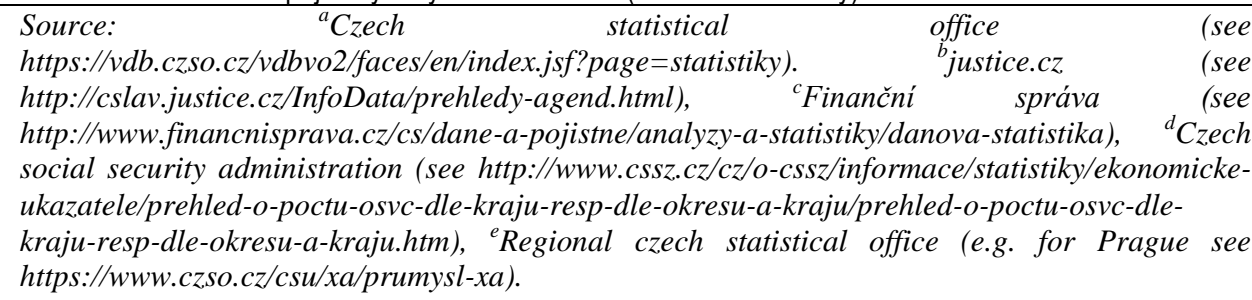 } \\
\hline
\end{tabular}


Appendix 2: Estimations of the size of the shadow economy in Czech regions (\% GDP)

\begin{tabular}{|c|c|c|c|c|c|c|c|c|c|c|c|}
\hline Region / Year & 2005 & 2006 & 2007 & 2008 & 2009 & 2010 & 2011 & 2012 & 2013 & 2014 & Rank \\
\hline $\begin{array}{l}\text { Czech Repub- } \\
\text { lic }\end{array}$ & 18.5 & 18.1 & 17.0 & 16.6 & 16.9 & 16.7 & 16.4 & 16.0 & 15.5 & 15.3 & - \\
\hline $\begin{array}{l}\text { Prague, } \\
\text { the Capital } \\
\text { City }\end{array}$ & 15.4 & 15.6 & 15.0 & 15.2 & 15.9 & 15.6 & 15.1 & 14.8 & 15.1 & 13.9 & 1 \\
\hline $\begin{array}{l}\text { Central Bohe- } \\
\text { mian Region }\end{array}$ & 17.7 & 17.6 & 16.4 & 16.3 & 16.9 & 16.7 & 16.3 & 16.0 & 15.3 & 15.0 & $5 / 6$ \\
\hline $\begin{array}{l}\text { South Bohe- } \\
\text { mian Region }\end{array}$ & 17.7 & 17.8 & 16.4 & 16.0 & 16.6 & 16.5 & 16.2 & 15.8 & 15.1 & 14.9 & 3 \\
\hline Plzeň Region & 17.8 & 17.7 & 16.6 & 16.4 & 17.0 & 16.8 & 16.4 & 15.7 & 15.2 & 15.2 & 7 \\
\hline $\begin{array}{l}\text { Karlovy Vary } \\
\text { Region }\end{array}$ & 19.6 & 19.6 & 18.4 & 18.1 & 19.1 & 18.8 & 18.2 & 17.7 & 17.2 & 16.7 & 14 \\
\hline $\begin{array}{l}\text { Ústí nad La- } \\
\text { bem Region }\end{array}$ & 19.5 & 19.4 & 17.8 & 17.2 & 18.1 & 17.7 & 17.2 & 16.8 & 16.6 & 16.2 & 13 \\
\hline $\begin{array}{l}\text { Liberec Re- } \\
\text { gion }\end{array}$ & 17.9 & 18.0 & 16.7 & 16.5 & 17.5 & 17.1 & 16.8 & 16.8 & 16.0 & 15.5 & 9 \\
\hline $\begin{array}{l}\text { Hradec Králo- } \\
\text { vé Region }\end{array}$ & 17.6 & 17.7 & 16.4 & 16.2 & 17.2 & 16.8 & 16.4 & 15.7 & 15.3 & 14.9 & $5 / 6$ \\
\hline $\begin{array}{l}\text { Pardubice } \\
\text { Region }\end{array}$ & 18.0 & 17.9 & 16.8 & 16.3 & 17.2 & 17.0 & 16.4 & 16.1 & 15.6 & 14.9 & 8 \\
\hline $\begin{array}{l}\text { Vysočina } \\
\text { Region }\end{array}$ & 18.5 & 18.3 & 17.2 & 16.7 & 17.4 & 17.1 & 16.7 & 16.2 & 15.7 & 15.2 & 10 \\
\hline $\begin{array}{l}\text { South Moravi- } \\
\text { an Region }\end{array}$ & 17.9 & 17.8 & 16.3 & 16.0 & 16.9 & 16.7 & 16.3 & 15.7 & 15.0 & 14.7 & 4 \\
\hline $\begin{array}{l}\text { Olomouc } \\
\text { Region }\end{array}$ & 18.7 & 18.5 & 17.1 & 16.7 & 17.3 & 17.3 & 16.8 & 16.1 & 15.6 & 15.3 & 11 \\
\hline $\begin{array}{l}\text { Moravian- } \\
\text { Silesian Re- } \\
\text { gion }\end{array}$ & 19.1 & 18.8 & 17.3 & 16.9 & 18.5 & 17.4 & 16.9 & 16.4 & 15.8 & 15.5 & 12 \\
\hline Zlín Region & 18.1 & 17.8 & 16.5 & 16.0 & 15.3 & 16.8 & 16.4 & 15.8 & 15.0 & 14.8 & 2 \\
\hline
\end{tabular}

